\title{
"Antecedents of employee wellbeing in the banking sector: the moderating role of working environment"
}

\begin{tabular}{|c|c|}
\hline \multirow{5}{*}{ AUTHORS } & Saba Gulzar (D) https://orcid.org/0000-0003-0639-6475 \\
\hline & $\begin{array}{l}\text { Shagufta Ghauri } \\
\text { Zuhair Abbas (D) https://orcid.org/0000-0003-2242-2848 }\end{array}$ \\
\hline & Kanwal Hussain (D https://orcid.org/0000-0002-1232-8412 \\
\hline & Abdul Bashiru Jibril (D https://orcid.org/0000-0003-4554-0150 \\
\hline & $\mathbb{R}$ https://www.researchgate.net/profile/Abdul_Bashiru_Jibril \\
\hline ARTICLE INFO & $\begin{array}{l}\text { Saba Gulzar, Shagufta Ghauri, Zuhair Abbas, Kanwal Hussain and Abdul } \\
\text { Bashiru Jibril (2020). Antecedents of employee wellbeing in the banking sector: } \\
\text { the moderating role of working environment. Problems and Perspectives in } \\
\text { Management, } 18(4), 448-460 \text {. doi:10.21511/ppm.18(4).2020.36 }\end{array}$ \\
\hline DOI & http://dx.doi.org/10.21511/ppm.18(4).2020.36 \\
\hline RELEASED ON & Tuesday, 22 December 2020 \\
\hline RECEIVED ON & Thursday, 15 October 2020 \\
\hline ACCEPTED ON & Monday, 30 November 2020 \\
\hline JOURNAL & "Problems and Perspectives in Management" \\
\hline ISSN PRINT & $1727-7051$ \\
\hline ISSN ONLINE & $1810-5467$ \\
\hline PUBLISHER & LLC "Consulting Publishing Company "Business Perspectives" \\
\hline FOUNDER & LLC "Consulting Publishing Company "Business Perspectives" \\
\hline
\end{tabular}

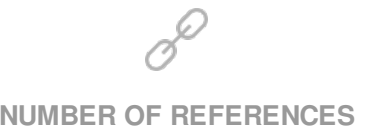

76

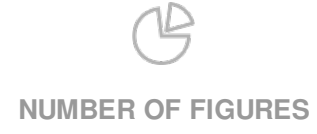

1
NUMBER OF TABLES

5

(C) The author(s) 2023. This publication is an open access article. 


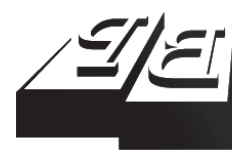

\section{BUSINESS PERSPECTIVES}

O

LLC "CPC "Business Perspectives"

Hryhorii Skovoroda lane, 10,

Sumy, 40022, Ukraine

www.businessperspectives.org
Saba Gulzar (Pakistan), Shagufta Ghauri (Pakistan), Zuhair Abbas (Czech Republic), Kanwal Hussain (Pakistan), Abdul Bashiru Jibril (Czech Republic/Ghana)
Received on: $15^{\text {th }}$ of October, 2020 Accepted on: $30^{\text {th }}$ of November, 2020 Published on: $22^{\text {nd }}$ of December, 2020

(c) Saba Gulzar, Shagufta Ghauri, Zuhair Abbas, Kanwal Hussain, Abdul Bashiru Jibril, 2020

Saba Gulzar, Doctoral Student, Senior Lecturer, Department of Management and HRM, Institute of Business Management (IoBM), Karachi, Pakistan.

Shagufta Ghauri, Ph.D., Assistant Professor, Department of Management and HRM, Institute of Business Management (IoBM), Karachi, Pakistan.

Zuhair Abbas, Doctoral Student, Research Scholar, Faculty of Management and Economics, Department of Business Administration, Tomas Bata University in Zlin, Czech Republic. (Corresponding author)

Kanwal Hussain, MS Student, Research Associate, Department of Management and HRM, Institute of Business Management (IoBM), Karachi, Pakistan.

Abdul Bashiru Jibril, Doctoral Student, Research Scholar, Faculty of Management and Economics, Department of Management and Marketing, Tomas Bata University in Zlin, Czech Republic; Faculty of Business \& Management Studies, Sunyani Technical University, Sunyani, Ghana.
This is an Open Access article, distributed under the terms of the Creative Commons Attribution 4.0 International license, which permits unrestricted re-use, distribution, and reproduction in any medium, provided the original work is properly cited.

Conflict of interest statement: Author(s) reported no conflict of interest

\section{ANTECEDENTS OF EMPLOYEE WELLBEING IN THE BANKING SECTOR: THE MODERATING ROLE OF WORKING ENVIRONMENT}

\begin{abstract}
This study examined the influence of work-life balance, work stress, employee engagement, and working environment on employee wellbeing in the banking sector of Pakistan. Due to complex human resource policies in Pakistan, employee wellbeing is neglected in several banking institutions; this study addresses a research gap in this way. Drawing upon job demands-resources theory, the study employed a quantitative methodology through a survey of 360 employees from private and public banks in Pakistan. The results from PLS-SEM (Partial Least Squares Structural Equation Modeling) demonstrate that employee engagement and work stress are significantly related to employee wellbeing, while working environment has a significant interactive effect between employee engagement and employee wellbeing. Theoretically, the study contributes to broadening the existing literature on human resource management. Practically, this study provides guidelines to human resource practitioners, managers, and policymakers on devising strategies for their employee wellbeing in going forward.
\end{abstract}

Keywords

wellbeing, personnel management, labor management, Pakistan

\section{JEL Classification I30, M12, M54}

\section{INTRODUCTION}

In the modern era, work-related stress has been greatly exacerbated by adversarial psychosocial working conditions. It is the organizations' responsibility to look after the mental health and well-being of employees (Johnson et al., 2020). It is imperative that the 'third goal' of Sustainable Development Goals (SDGs) of the United Nations is to focus on "good health and wellbeing," which has increased awareness and importance among policymakers and researchers globally (George et al., 2016). In this light, any country's financial system is a vital institute, and the banking system has been professed as a hub of the financial system (Kaur \& Sandhu, 2010).

Despite the literature available on employee wellbeing, there is a dearth of studies in developing countries, especially in Pakistan. It is argued that exploring the antecedents of employee wellbeing, notably, worklife balance, work stress, employee engagement, and working environment on employee wellbeing, would reveal explanations why organizations should formulate employee-friendly policies at the workplace, which has been ignored in earlier studies (Kossek et al., 2014). This study provides guidelines to managers about ways to improve employee wellbeing in the workplace. 
Although working environment and work stress also play a vital role, the prime concern is that every organization should ensure a sound work-life balance. While studies on this concern are quite rare (Greenhaus \& Allen, 2011; Haar et al., 2014), it focuses on the intra-individual transfer of balance. Therefore, management research needs to strive for a higher impact in a competitive labor market (George, 2016). Evidence suggests that employees who perceive work-life balance and are effective in life roles tend to have a higher sense of employee wellbeing (Lyness \& Judiesch, 2014). Though, employee engagement has been defined as a distinctive and novel construct comprising cognitive, emotional, and behavioral components allied with individual role performance (Saks, 2006).

In a nutshell, employees' competitiveness and sustainability in the service sector in the last decade have continued to trigger scholars' interest in this subject matter (Hussain et al., 2020). Therefore, the main purpose of this study is to address the contextual gap by conducting a study in banks on employee wellbeing, which is linked to employee performance. This study also broadens the empirical evidence in the field of human resource management. Again, it is also imperative to reiterate the antecedents of this research theme, such as work-life balance, work stress, employee engagement, and working environment about employee wellbeing. To implement this goal, this study encompasses the literature by applying job demands-resources theory (JD-R) in precise by opening up the scientific discussion about the comparisons that underlie JD-R.

\section{LITERATURE REVIEW, CONCEPTUAL FRAMEWORK, AIMS AND HYPOTHESES DEVELOPMENT}

\subsection{Job demands-resources theory (JD-R)}

Job demands-resources (JD-R) theory is related to the work-linked features that influence employees' job execution, physical and psychological wellbeing (Hobfoll, 2001). According to Schaufeli (2013), an individual's job and personal traits combine to reinforce high levels of engagement. The theory explains how job characteristics and job performance are related (Menguc et al., 2017). In recent research by Kim and Beehr (2018), there is a difference between job demands, challenges, and obstacles. Eldor (2017) argues that employees feel bored due to high job demands at the workplace. Employees face psychological and health issues due to job demands at the workplace (Bakker et al., 2007; Hakanen et al., 2006). More importantly, multiple factors, such as learning and personal development, reduce job demands (Bakker \& Demerouti, 2017).

The World Health Organization has defined wellbeing as "a comprehensive condition of mental, physical and social wellbeing, not only lack of infirmity or disease". Durand (2015) stated in his study that the OCED has lately established a range of parameters of wellbeing as a fragment of 'better life' inventiveness. He also focused on the subjective wellbeing that is defined as 'a good mental state that comprises of numerous optimistic and negative evaluations that individuals make of their lives and the affective response of people and their experience.' In this era, work-life balance is a foremost concern of employees working in an organization, especially if they were given flexible working arrangements. It is recommended that there be a balance between working hours and employees' workload (Haddon, 2018). Petrou et al. (2012) emphasize that an individual who is provided with work-life balance opportunities has more satisfied and committed attitudes at the workplace. According to their research findings, they found a positive relationship between work-life balance and employee wellbeing. Enehaug et al. (2016) explored the correlation between worklife balance and employee wellbeing. According to the world population, the sixth highly populated country in the world is Pakistan, with 210 million people (Worldometer, 2020). The banking sector in Pakistan is deliberated as a leading industry with diverse branches across the country. As stated by the State Bank of Pakistan (SBP, 2020), many individuals are working under the 
umbrella of the banking industry after its reform in the early 1990s. In banks, work conditions have changed drastically in the last two decades (Khilji, 2006).

According to Sonnentag and Frese (2012), work stress is associated with a maximum number of possible outcomes. Although several studies are related to stressor-to-strain relationships, few other studies look into the inverse relationship, i.e., from wellbeing to job stressors, and have published empirical support by Ford et al. (2014). However, Friedenreich et al. (2016) found that few studies failed to determine the negative relationship between work stress and employee wellbeing.

The researchers have generally neglected the importance of work stress at the workplace (Eldor, 2017). According to McDonald and Westphal (2013), work stress created an equal impact on male-female employees because the work stress was more or less similar for each employee. Importantly, Beehr et al. (2001) argued that stress is always a response from emotional problems, so it is the organization's responsibility to provide emotional stability to its employees. At least employees should be given less pressure from the employer. This study has analyzed that work stress is significantly related to employee wellbeing (Hendrie \& Pickles, 2010; Nesse, 2000).

Employee engagement research has gained encouragement (Albrecht et al., 2010). The cognitive, emotional, and behavioral energy boost the performance of employees and organizations by their engagement at the workplace concepts of job demand and job/personal resources. The idea of employee engagement is crucial to management, and there is limited research about this new construct (Saks, 2006).

In almost every organization employee who is a high achiever is always in demand. When an employee feels that they have independence in decision-making power and can give feedback on their work, it leads to engagement and satisfaction (Truss et al., 2013). When an employee can work independently and have authority and empowerment, it refers to employee engagement. Therefore, employees who have decision-making power and autonomy of work do not need to take permission for each decision and feel more satisfied and contribute to the organization's progress. According to Truss et al. (2013), employee engagement has always been a problem associated with wellbeing, and it has also been substantiated by earlier literature. It is a crucial relationship concerning organizational performance because it is obvious that employees having mental peace always benefit their organization through their performance. According to Tan et al. (2020), there is a strong relationship between employee engagement and wellbeing.

Kossek, T. Kalliath, and P. Kalliath (2012) suggest that the changing environment is important for employee wellbeing. According to T. Kalliath and P. Kalliath (2012), many organizations focused on flexible working hours to cater to their employees according to their time convenience for work. In the flexible working schedule, they offered flexible working and reduced working hours, minimizing the mental pressure on employees. Grant, Wallace, and Spurgeon (2013) perceive that the evolution of technology has enabled them to work remotely. According to Grant, Wallace, and Spurgeon (2013), this nature of work could adversely affect employee health. The wellbeing of an employee is related to various factors such as age. Warr (2003) and Zacher et al. (2014) have demonstrated that the welfare of employees reduces as the age of an employee increases. However, further studies are required to investigate the role of the physical working environment on employee mental health (Tan et al., 2020). Nielsen et al. (2017) highlighted the workplace environment and its impact on employee health. They considered that if the employee is paid a salary for his work, there is no need to improve their working conditions. A few studies on the working environment indicate that employee wellbeing is strongly affected by the working conditions. They include a healthy relationship with peers, a manageable workload, leading practices, and autonomy for work (Nielsen et al., 2017).

The current study addresses the research gap and aims to:

1) examine the factors that impact employee wellbeing in the banking sector; 
2) assess the moderating effect of working environment between work-life balance, work stress, employee engagement, and employee wellbeing in the banking sector.

To implement the aims stated above, the paper hypothesizes the following:

H1: Work-life balance is positively associated with employee wellbeing.

H2: Work stress significantly affects employee wellbeing.

H3: Employee engagement is positively associated with employee wellbeing.

H4: Working environment moderates the relationship between work-life balance and employee wellbeing.

H5: Working environment moderates the relationship between work stress and employee wellbeing.

H6: Working environment moderates the relationship between employee engagement and employee wellbeing.

From the literature review, the research constructs (see Table 1) and the conceptual framework (see Figure 1) and their hypotheses are summarized.

\section{DATA AND METHODS}

\subsection{Measurement of constructs}

It was noted that the items used for measuring the constructs were adapted from the existing literature. Therefore, it is important to mention that a seven-point Likert scale was used to measure all items ranging from $1=$ Strongly disagree to $7=$ Strongly agree, and all the items were in affirmative statements. The measurement scale for work-life balance was taken from Tasnim et al. (2017), work stress items were adopted from the study of Leung et al. (2011), employee engagement items were taken from Schaufeli (2013), working environment items were adopted from McGuire and McLaren (2009), and employee wellbeing items were adopted from Zheng et al. (2015).

\subsection{Data collection and analytic technique}

This study adopted the survey method approach, and its philosophical positioning is the positivism paradigm. It used an explanatory research model that proposed an examination of how one variable impacts the other variables (Cooper \& Schindler, 2001; Creswell, 2012; Hartono, 2013). The sample consists of branch managers, operation managers, senior branch officers in services, customer relationship officers, branch service officers in cash,

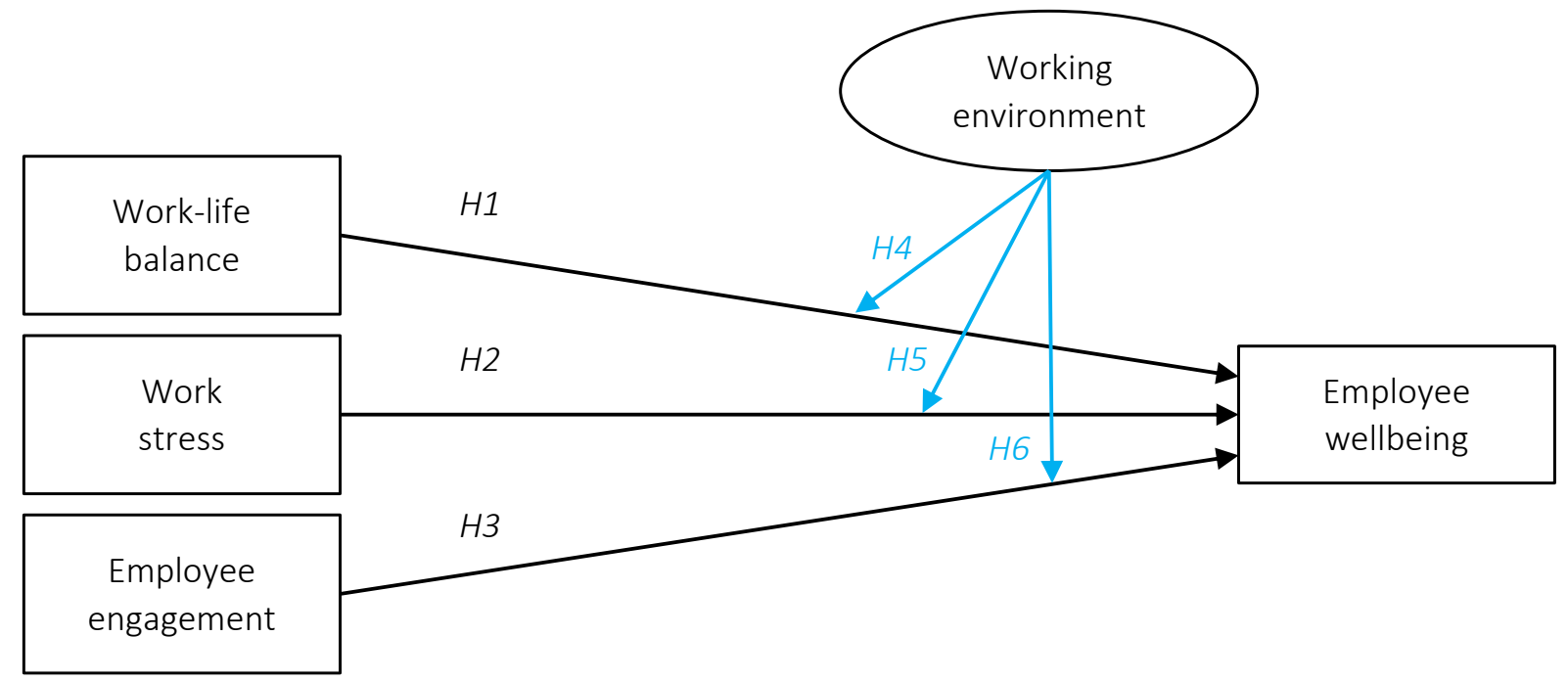

Figure 1. Research model 
and sales officers from public and private sector banks from the metropolis city Karachi, situated in the Sindh province of Pakistan. This study adopted a convenience sampling technique to collect data from employees working in public and private banks. The data were collected from one province (Sindh) of Pakistan as it is an industrial hub of Pakistan. According to Etikan et al. (2016), the technique was adopted due to respondents' convenience, geographical nearness, eagerness to participate, participants' ease of access to the investigator, and affordability in terms of the cost related to the accomplishment unit of analysis.

The period to collect the data was from September to December 2019. The confidentiality of information was assured after sending a letter of participation to respondents (Khuwaja et al., 2020). The average time to fill the questionnaire was 5 minutes. Out of 500 samples, only 360 respondents signifying $72 \%$, were valid for data analysis. The demographic summary of the respondents with frequency and percentage is illustrated in Table 1.

Table 1. Demographic distribution of respondents
Table 1 indicates that the sample of this study consisted of $55.55 \%$ male employees, while $44.44 \%$ are female employees working in banks. $55 \%$ of the respondents were aged between 30 to 40 years. At the educational level, $56.11 \%$ of respondents were holding a Bachelor's degree. $63.61 \%$ of employees worked in private sector banks, while $36.38 \%$ were working in public sector banks. Most of the employees had 6 to 10 years of experience in banks, with $54.44 \%$. The bank manager population consisted of $16.11 \%$, while $24.16 \%$ were senior branch officers-services.

\section{RESULTS}

\subsection{Model assessment}

Conferring to the pioneer specialists Hair et al. (2017), it is significant to assess the constructs' reliability using Composite Reliability besides Cronbach's Alpha coefficients. Table 2 indicates that all the values surpassed the threshold

Source: Field data, September - December 2019, Karachi, Sindh, Pakistan.

\begin{tabular}{|c|c|c|c|}
\hline Demographic variable & Characteristic & Frequency & Percentage (\%) \\
\hline \multirow{3}{*}{ Gender } & Male & 200 & 55.56 \\
\hline & Female & 160 & 44.44 \\
\hline & Total & 360 & 100 \\
\hline \multirow{5}{*}{ Age } & Below 30 & 67 & 18.40 \\
\hline & $30-40$ & 198 & 55.22 \\
\hline & $40-50$ & 55 & 15.27 \\
\hline & 50 and above & 40 & 11.11 \\
\hline & Total & 360 & 100 \\
\hline \multirow{3}{*}{ Educational level } & Bachelor's & 202 & 56.12 \\
\hline & Master's & 158 & 43.88 \\
\hline & Total & 360 & 100 \\
\hline \multirow{4}{*}{ Work experience } & $1-5$ years & 69 & 19.16 \\
\hline & $6-10$ years & 196 & 54.44 \\
\hline & Above 10 years & 95 & 26.40 \\
\hline & Total & 360 & 100 \\
\hline \multirow{7}{*}{ Position level } & Branch manager & 58 & 16.11 \\
\hline & Operational manager & 61 & 16.94 \\
\hline & Senior branch officer-services & 87 & 24.16 \\
\hline & Customer relationship officer & 77 & 21.38 \\
\hline & Branch service officer-cash & 42 & 11.66 \\
\hline & Sales officer & 35 & 9.75 \\
\hline & Total & 360 & 100 \\
\hline \multirow{3}{*}{ Affiliation with the bank } & Public sector & 131 & 36.38 \\
\hline & Private sector & 229 & 63.62 \\
\hline & Total & 360 & 100 \\
\hline
\end{tabular}

Note: $N=360$ (sample size). 
of 0.5 , indicating strong coefficients of the construct's reliability as recommended by Henseler and Schuberth (2020). It is always recommended to test the reliability and validity of the constructs. The reliability was measured through Cronbach's Alpha and Composite Reliability for every item with its respective construct (Hair et al., 2012), whereas the validity test was conducted with the support of AVE (Average Variance Extracted). Studies have been supportive (Hair et al., 2012). To accept construct reliability through Cronbach's Alpha, the minimum threshold value must be 0.060 , and Cronbach's Alpha value is 0.70 (Bagozzi, Yi, \& Nassen, 1998). Remarkably, the estimations from PLS-SEM met the threshold mentioned above, consequently signifying the reliability of the essential research constructs.

Additionally, the PLS-SEM has entrenched indices for assessing both reliability and validity as Composite Reliability of construct and Average Variance Extracted (AVE) in the model (Bollen, 1989; Hair et al., 2012). The threshold for Composite Reliability determinant is 0.8 , which fulfills the analysis of this research. Consequently, CR (Composite Reliability) of the research constructs have a minimum reliability coefficient of 0.7760 and a maximum of 0.8585 , whereas the convergent validity with Average Variance Extracted (AVE) was presented, which also surpassed the minimum threshold of 0.5 as mentioned in Table 2.

Table 2. Construct reliability and validity

\begin{tabular}{l|c:c|c} 
& \multicolumn{3}{c}{ Source: Authors' processing from SmartPLS version 3.0. } \\
\hline \multicolumn{1}{c}{ Construct } & CR(> 0.7) & AVE & CA $(\alpha)$ \\
\hline $\begin{array}{l}\text { Work-Life } \\
\text { Balance (WLB) }\end{array}$ & 0.8127 & 0.5925 & 0.6672 \\
\hdashline $\begin{array}{l}\text { Work Stress } \\
\text { (WS) }\end{array}$ & 0.8341 & 0.5080 & 0.7529 \\
\hdashline $\begin{array}{l}\text { Employee } \\
\text { Engagement }\end{array}$ & 0.8159 & 0.5289 & 0.6992 \\
\begin{tabular}{l} 
(EE) \\
\hdashline $\begin{array}{l}\text { Working } \\
\text { Environment }\end{array}$ \\
(WE)
\end{tabular} & 0.8291 & 0.6230 & 0.7443 \\
\hdashline $\begin{array}{l}\text { Employee } \\
\text { Wellbeing (EWB) }\end{array}$ & 0.8585 & 0.6707 & 0.7599 \\
\hline
\end{tabular}

Note: $\mathrm{CR}=$ Composite Reliability, $\mathrm{AVE}=$ Average Variance Extracted, $\mathrm{CA}=$ Cronbach's Alpha.

Regarding the indicator loadings of the covert constructs, all items were loaded implicitly to their conforming construct. The measured indicators have maximum loadings of nearly 0.9 and minimum loadings of nearly 0.5 . Bagozzi, Yi, and Nassen (1998) stated that the best measurement of a latent variable under study should have a loading above the threshold of 0.6. These indicator variables have a maximum load of 0.884 and a minimum load of 0.551 , and this specifies the measure of what they should measure. Therefore, Table 3 summarizes all the research constructs with their measurement items and corresponding coefficients (loadings).

\subsubsection{Coefficient of determination (R-squared)}

Concerning the research constructs' predictive power, the coefficient of determination $\left(R^{2}\right)$ of the regression model was measured. The predictor (independent) variable explains the coefficient that specifies the proportion of the difference in the dependent variable. The $R^{2}$ of WLB (0.001) exhibited a $1 \%$ variation in the construct. The construct's EWB describes WLB. The adjusted $R^{2}$ shows the variance in the endogenous construct explicated by the exogenous construct. Table 3 shows that the estimated $R^{2}$ of EE (0.012) indicated that $1.2 \%$ of the EE variation is explicated by the construct EWB as an independent variable. At the same time, model $R^{2}$ of the dependent variable EWB (0.16) specifies $16 \%$ of the total variation of the construct. In Table 3, EWB is explicated by individual constructs' collective effect: EE, WLB, WS, and WE.

Table 3. Measurement model for constructs

Sources: Authors' estimations from SmartPLS version 3.0.

\begin{tabular}{|c|c|c|c|}
\hline Constructs & Indicator & $\begin{array}{l}\text { Factor } \\
\text { loadings }\end{array}$ & VIF \\
\hline \multirow{3}{*}{$\begin{array}{l}\text { Work-Life Balance (WLB) }\left(R^{2}\right. \\
=0.001)\end{array}$} & WLB1 & 0.718 & 1.314 \\
\hline & WLB3 & 0.846 & 1.277 \\
\hline & WLB4 & 0.738 & 1.305 \\
\hline \multirow{4}{*}{$\begin{array}{l}\text { Employee Engagement }(\mathrm{EE}) \\
\left(R^{2}=0.012\right)\end{array}$} & EE1 & 0.745 & 1.539 \\
\hline & EE2 & 0.602 & 1.329 \\
\hline & EE4 & 0.712 & 1.63 \\
\hline & EE5 & 0.832 & 1.806 \\
\hline \multirow{5}{*}{ Work Stress (WS) $\left(R^{2}=0.13\right)$} & WS1 & 0.551 & 1.229 \\
\hline & WS3 & 0.586 & 1.296 \\
\hline & WS4 & 0.842 & 2.051 \\
\hline & WS5 & 0.746 & 1.669 \\
\hline & WS6 & 0.791 & 1.822 \\
\hline \multirow{3}{*}{$\begin{array}{l}\text { Working Environment (WE) } \\
\left(R^{2}=0.001\right)\end{array}$} & WE2 & 0.837 & 2.535 \\
\hline & WE3 & 0.621 & 1.545 \\
\hline & WE4 & 0.884 & 2.086 \\
\hline \multirow{3}{*}{$\begin{array}{l}\text { Employee Wellbeing (EWB) } \\
\left(R^{2}=0.16\right)\end{array}$} & EWB4 & 0.875 & 1.987 \\
\hline & EWB5 & 0.852 & 1.518 \\
\hline & EWB6 & 0.72 & 1.523 \\
\hline
\end{tabular}


The items whose factor loading threshold value was less than 0.60 were deleted (EE3, EE6, WLB2, WS2, WE1, WE5, WE6, EWB1, EWB2, EWB3, and EWB7). Simultaneously, to establish discriminant validity, the criterion was used to measure the existence of discriminant validity among the covert variables (Henseler et al., 2015). The findings from Fornell-Lacker criterion specified that constructs fulfill both stringent and basic assumptions and establish discriminant validity. It is significant to note the values in bold (diagonal) of the Fornell-Lacker criterion. Table 4 specifies AVE's of the measured constructs and must be greater than 0.5. AVE should be of higher value (coefficient) at both column and row position over other constructs to establish discriminant validity (Fornell \& Larcker, 1981).

Table 4. The measurement model discriminant validity - Fornell-Lacker criterion

Source: Authors' estimations from SmartPLS version 3.0.

\begin{tabular}{l|c|c|c|c|c}
\hline \multicolumn{1}{c}{ Constructs } & $\mathbf{1}$ & $\mathbf{2}$ & $\mathbf{3}$ & $\mathbf{4}$ & $\mathbf{5}$ \\
\hline EE & 0.727 & & & & \\
EWB & 0.115 & 0.819 & & & \\
\hline WE & -0.013 & -0.069 & 0.789 & & \\
WLB & -0.037 & -0.046 & 0.615 & 0.771 & \\
WS & 0.058 & 0.365 & -0.062 & -0.012 & 0.713 \\
\hline
\end{tabular}

Note: $\mathrm{EE}=$ Employee Engagement, $\mathrm{EWB}=$ Employee Wellbeing, WE = Working Environment, WLB = Work-Life Balance, WS = Work Stress, $N=360$. Squared correlations; AVE in the diagonal (in bold).

The capacity of survey data collection instrument questions to capture data for its defined tenacity and distinguish themselves from other questions with construct and in between construct is measured through the test of discriminant validity by employing the Fornell-Larcker criterion (Hair et al., 2010). The Partial Least Squares Structural Equation Modeling (PLS-SEM) has been employed to calculate the value of the Fornell-Larcker criterion (Fornell \& Larcker, 1981). The value of the Fornell-Larcker criterion of each construct should be higher than its contiguous value, and a higher value shows that each construct is different from the other and extends to only its relevant phenomena (Hamid et al., 2017). Therefore, the FornellLarcker criterion results of the current study show that every construct reports a higher value on its construct and a lower value on the contiguous construct. Thus, it can be concluded that the Fornell-Larcker criterion has been achieved.

\subsection{Structural model}

Proceeding from the model fit assessment, the structural model (path analysis) of the hypotheti$\mathrm{cal}$ analysis is required. Noticeably, it is relevant to achieve this stage of the analysis since it identifies and establishes the causal effect or relationships of the underlying research aim's constructs. The results reveal the direct and indirect effects of factors that trigger employee wellbeing in the banking sector of Pakistan. Regarding the direct effect, the result revealed that the constructs: Employee Engagement (EE) and Work Stress (WS) have a significant effect on Employee Wellbeing (EWB) with $(\beta=0.105, t=1.972)$ and $(\beta=0.341, t=8.202)$, respectively. However, Work-Life Balance (WLB) has no significant direct effect on EWB with $(\beta=$ $-0.038, t=0.569)$, as seen in Table 5 .

Whereas concerning indirect (moderation) effect, the result was quite interesting, in that, with all three moderated hypotheses, only one

Table 5. Path coefficient for a direct and indirect relationship

Source: Authors' processing from SmartPLS version 3.0.

\begin{tabular}{|c|c|c|c|c|c|}
\hline Effect & $\begin{array}{c}\text { Original } \\
\text { coefficient }(\boldsymbol{B})\end{array}$ & Mean value & $t$-value & $p$-value & Empirical remarks \\
\hline \multicolumn{6}{|c|}{ Direct effect } \\
\hline$H 1: \mathrm{EE} \rightarrow \mathrm{EWB}$ & 0.105 & 0.1175 & 1.972 & 0.0488 & Supported \\
\hline H2: WLB $\rightarrow$ EWB & -0.038 & -0.043 & 0.569 & 0.5689 & Not supported \\
\hline H3: WS $\rightarrow$ EWB & 0.341 & 0.3503 & 8.202 & 0.0000 & Supported \\
\hline \multicolumn{6}{|c|}{ Indirect (moderation) effect } \\
\hline H4: WE: WLB $\rightarrow$ EWB & -0.041 & -0.0188 & 0.559 & 0.5759 & Not supported \\
\hline H5: WE: WS $\rightarrow$ EWB & -0.106 & -0.0513 & 0.964 & 0.335 & Not supported \\
\hline H6: WE: EE $\rightarrow$ EWB & 0.203 & 0.1104 & 4.032 & 0.0001 & Supported \\
\hline
\end{tabular}

Note: $B=$ regression coefficient and $t=$ significant value $(t>1.96$ or $p<0.05)$, EE $=$ Employee Engagement, EWB $=$ Employee Wellbeing, WE $=$ Working Environment, $\mathrm{WLB}=$ Work-Life Balance, $\mathrm{WS}=$ Work Stress. 
was significant. Thus, the construct Working Environment (WE) as a moderating variable plays a significant moderation role between the interaction of EE and EWB with $(\beta=0.203, t$ $=4.032$ ). It suggests that the working environment of employees determines the motivation level towards their zeal in the execution of their job, which would consequently boost the level of morale in their quest to achieve organizational goals and objectives (see Table 5).

\section{DISCUSSION}

This study considers it important to examine the work-life balance, work stress, employee engagement, and working environment with employee wellbeing in the banking sector, more importantly, all employees affected by the negative consequences of the wellbeing program. $\mathrm{H1}$ result demonstrates that employee engagement has a direct and positive impact on employee wellbeing. The result is in line with the recent research by Rahman, Björk, and Ravald (2020); they discovered that employee engagement has a positive relationship with employee wellbeing. The second $\mathrm{H} 2$ found that work-life balance has no relationship with employee wellbeing in this study. Thus, the finding contradicts a study by Fotiadis et al. (2019); they found that work-life balance is associated with wellbeing.

It is also interesting to note that $\mathrm{H3}$ found that work stress is positively associated with employee wellbeing in the banking sector. This study is in line with a study by Ross (1995); work stress is a crucial issue being faced by employees and managers, which leads to the impact on organizational performance and their wellbeing at the workplace. According to $\mathrm{H} 4$ and $\mathrm{H} 5$, working environment has no moderating effect on work-life balance and work stress with employee wellbeing. Conversely, this study found that according to H6, working environment moderates the relationship between employee engagement and employee wellbeing. This study is in line with the result of Saleem et al. (2020); they found that working environment positively impacts employee engagement.

\subsection{Research implications}

This study has provided two practical implications. Firstly, top management of organizations formulates employee-oriented policies that improve the wellbeing of employees at the workplace. Employees face several hurdles, such as work stress, high workload, work and family issues due to work. The workplace dynamics affect the employees' health and affect them psychologically due to a pressured working environment and high targets from managers. Secondly, this study tries to provide comprehensive advice for managers on how they should develop policies regarding flexible working hours for their employees. Employees are assets of organizations, so they must take care of their employees to achieve competitive advantage and reduce turnover. It will affect the overall performance of businesses.

This study has several meaningful contributions to the body of knowledge. First, this study empirically examined how work-life balance, work stress, employee engagement, and working environment influence employee wellbeing. Second, this study contributes to broadening the human resource management (HRM) literature as it gives deeper insights to scholars concerning the new line of research. Third, this study enriches the existing literature of job demands-resources theory. Fourth, the research model would offer a basic understanding and serves as leverage to researchers in future studies concerning the current theme under study.

\section{CONCLUSION}

This study contributes to the body of knowledge on employee wellbeing at the workplace by examining employees' engagement, work-life balance, work stress, and working environment in the banking sector of Pakistan. More importantly, the findings of this study reveal that Employee Engagement (EE) and Work Stress (WS) have a significant effect on Employee Wellbeing (EWB). This finding suggested that engagement with peers and managers improves their wellbeing at the 
workplace. However, work stress affects employees' performance and wellbeing due to long working hours when dealing with many customers in banks. Unexpectedly, Work-Life Balance (WLB) did not find sufficient evidence with employee wellbeing. Subsequently, an important finding to emerge in this study was Working Environment (WE) as a moderating variable, which plays a significant moderation effect between the interaction of EE and EWB, thus deviating from traditional thoughts and providing a fresh perspective on the subject matter. The findings of this study broaden the understanding of employee wellbeing in the redesign and adjust policies and strategies in the banking institutions. Notably, this study also provides guidelines to human resource practitioners, managers, and policymakers on devising strategies for their employee wellbeing programs to boost performance at the workplace while boosting their morale.

This study has few limitations, which paves the way for future research to understand the relationships examined in this study. Firstly, this study was conducted in a developing country such as Pakistan (South-Asian region); hence, future research could be conducted in developed regions such as Europe, Australia, the USA, the UK, and Japan. Secondly, this study focused only on one service sector; therefore, future research may test the model in other equally important sectors/ industries such as textile, oil and gas, cement, pharmaceutical, and other sectors such as tourism, education, hotel, and hospitality. Thirdly, the model of this study is revealed around a few predictors of employee wellbeing. Future research could also explore this subject matter by considering 'work stress' as a mediator variable to get interesting results about employee wellbeing. Therefore, this study encourages future researchers to replicate the model on two-way aspects: top managers and sales teams in the banks.

\section{AUTHOR CONTRIBUTIONS}

Conceptualization: Saba Gulzar, Shagufta Ghauri.

Data curation: Saba Gulzar, Shagufta Ghauri.

Formal analysis: Zuhair Abbas, Kanwal Hussain.

Funding acquisition: Zuhair Abbas, Abdul Bashiru Jibril.

Investigation: Saba Gulzar, Shagufta Ghauri.

Methodology: Kanwal Hussain.

Project administration: Saba Gulzar, Shagufta Ghauri.

Resources: Saba Gulzar, Shagufta Ghauri.

Software: Abdul Bashiru Jibril.

Supervision: Saba Gulzar, Shagufta Ghauri.

Validation: Saba Gulzar, Shagufta Ghauri, Zuhair Abbas.

Visualization: Saba Gulzar, Shagufta Ghauri, Abdul Bashiru Jibril.

Writing - original draft: Saba Gulzar, Shagufta Ghauri, Zuhair Abbas, Kanwal Hussain.

Writing - review \& editing: Saba Gulzar, Shagufta Ghauri, Kanwal Hussain, Abdul Bashiru Jibril.

\section{ACKNOWLEDGMENT}

This work was supported by the Internal Grant Agency of Tomas Bata University in Zlin under the Projects No. FaME TBU No. IGA/FaME/2020/010 and IGA/FaME/2019/008. The authors would like to extend their appreciation to Prof. Boris Popesko (Vice-Dean for Research and Business Liaison) at the Faculty of Management and Economics for facilitating the financial readiness of this project. 


\section{REFERENCES}

1. Albrecht, S. L., Bakker, A. B., Gruman, J. A., Macey, W. H., \& Saks, A. M. (2015). Employee engagement, human resource management practices and competitive advantage. Journal of Organizational Effectiveness: People and Performance. https://doi.org/10.1108/JOEPP-08-2014-0042

2. Bagozzi, R. P., Yi, Y., \& Nassen, K. D. (1998). Representation of measurement error in marketing variables: Review of approaches and extension to three-facet designs. Journal of Econometrics, 89(1-2), 393-421. https://doi.org/10.1016/S03044076(98)00068-2

3. Bakker, A. B., Hakanen, J. J., Demerouti, E., \& Xanthopoulou, D. (2007). Job resources boost work engagement, particularly when job demands are high. Journal of Educational Psychology, 99(2), 274. https://doi org/10.1037/0022-0663.99.2.274

4. Bakker, A. B., \& Bal, M. P. (2010). Weekly Work Engagement and Performance: A Study among Starting Teachers. Journal of Occupational and Organizational Psychology, 83(1), 189-206 https://doi. org/10.1348/096317909X402596

5. Beehr, T. A., Glaser, K. M., Canali, K. G., \& Wallwey, D. A. (2001). Back to basics: Re-examination of Demand-Control Theory of Occupational Stress. Work \& Stress, 15(2), 115-130 https://doi. org/10.1080/02678370110067002

6. Bakker, A. B., \& Demerouti, E. (2017). Job demands-resources theory: taking stock and looking forward. Journal of Occupational Health Psychology, 22(3), 273. https://doi.org/10.1037/ ocp0000056

7. Bell, A. S., Rajendran, D., \& Theiler, S. (2012). Job Stress, Wellbeing, Work-Life Balance and Work-Life Conflict among Australian Academics. E-Journal of Applied Psychology, 8(1). https:// psycnet.apa.org/doi/10.7790/ejap. v8i1.320
8. Bollen, K. A. (1989). Structural Equations with Latent Variables. New York: John Wiley \& Sons.

9. Boyd, N. M., \& Nowell, B. (2020). Sense of Community, Sense of Community Responsibility, Organizational Commitment and Identification, and Public Service Motivation: a Simultaneous Test of Affective States on Employee Well-being and Engagement in a Public Service Work Context. Public Management Review, 1-27. https://doi.org/10.1080/14719037. 2020.1740301

10. Christian, M. S., Garza, A. S., \& Slaughter, J. E. (2011). Work engagement: A Quantitative Review and Test of its Relations with Task and Contextual Performance. Personnel Psychology, 64(1), 89-136. https://doi.org/10.1111/j.17446570.2010.01203.x

11. Cooper, D., \& Schindler, P. (2001). Business Research Method (International edition). McGraw Hill.

12. Creswell, J. W. (2012). Research design: Qualitative, Quantitative and Mixed Methods Approaches. Sage Publication.

13. Durand, J. D. (2015). The labor force in economic development: a comparison of international census data, 1946-1966. Princeton University Press. Retrieved from https://books.google.com.pk/boo $\mathrm{ks}$ ?hl=en\&lr=\&id=RmF9BgAAQ $\mathrm{BAJ} \& \mathrm{oi}=$ fnd $\& \mathrm{pg}=\mathrm{PP} 1 \& \mathrm{dq}=13 . \%$ 09Durand,+J.+D.+(2015).+The+ labor+force+in+economic+devel opment:+a+comparison+of+inte rnational+census+data, +194619 66.+Princeton+University+Press . \&ots=wPivzAD2_k\&sig=AoOU7 VPpB81wLBy7n6FfpLIz6BA\&red ir_esc $=\mathrm{y} \# \mathrm{v}=$ onepage $\& \mathrm{q} \& \mathrm{f}=$ false

14. Eldor, L. (2017). Looking on the bright side: The positive role of Organizational politics in the relationship between employee engagement and performance at work. Applied Psychology, 66(2), 233-259. https://doi.org/10.1111/ apps. 12090
15. Enehaug, H., Helmersen, M., \& Mamelund, S.-E. (2016). Individual and organizational wellbeing when workplace conflicts are on the agenda. A mixed methods study. Retrieved from http://hdl.handle.net/10642/3273

16. Etikan, I., Musa, S. A., \& Alkassim, R. S. (2016). Comparison of convenience sampling and purposive sampling. American Journal of Theoretical and Applied Statistics, 5(1), 1-4. https://doi. org/10.11648/j.ajtas.20160501.11

17. Ferguson, K. L., \& Reio, T. G. (2010). Human Resource Management Systems and firm performance. Journal of Management Development. https://doi. org/10.1108/02621711011039231

18. Ford, M. T., Matthews, R. A., Wooldridge, J. D., Mishra, V., Kakar, U. M., \& Strahan, S. R. (2014). How do occupational stressor-strain effects vary with time? A review and meta-analysis of the relevance of time lags in longitudinal studies. Work \& Stress, 28, 9-30. https://doi.org/10. 1080/02678373.2013.877096

19. Fornell, C., \& Larcker, D. F. (1981). Evaluating structural equation models with unobservable variables and measurement error. Journal of Marketing Research, 18(1), 39-50. https://doi. org/10.1177/002224378101800104

20. Fotiadis, A., Abdulrahman, K., \& Spyridou, A. (2019). The mediating roles of psychological autonomy, competence and relatedness on work-life balance and well-being. Frontiers in Psychology, 10, 1267. Retrieved from https://www.frontiersin.org/ articles/10.3389/fpsyg.2019.01267/ full

21. Fox, M. L., Dwyer, D. J., \& Ganster, D. C. (1993). Effects of stressful job demands and control on physiological and attitudinal outcomes in a hospital setting. Academy of Management Journal, 36(2), 289-318. https://doi. org/10.5465/256524 
22. Friedenreich, C. M., Pialoux, V., Wang, Q., Shaw, E., Brenner, D. R., Waltz, X., \& Poulin, M. J. (2016). Effects of exercise on markers of oxidative stress: an Ancillary analysis of the Alberta Physical Activity and Breast Cancer Prevention Trial. BMJ Open Sport \& Exercise Medicine, 2(1), e000171. http://dx.doi.org/10.1136/bmjsem-2016-000171

23. George, G. (2016). Management research in AMJ: Celebrating impact while striving for more. Academy of Management Journal, 59, 1869-1877. http://dx.doi. org/10.5465/ amj.2016.4006

24. George, G., Howard-Grenville, J., Joshi, A., \& Tihanyi, L. (2016). Understanding and Tackling Societal Grand Challenges through management research. Academy of Management Journal, 59, 1880-1895. http://dx.doi. org/10.5465/amj.2016.4007

25. George, J. M. (2011). The wider context, costs, and benefits of work engagement. European Journal of Work and Organizational Psychology, 20(1), 53-59. https://doi.org/10.1080/135 9432X.2010.509924

26. Greenhaus, J., \& Allen, T. (2011). Work-family balance: A review and extension of the literature. In J. C. Quick \& L. E. Tetrick (Eds.), Handbook of occupational health psychology (2nd ed.). Washington, DC: American Psychological Association.

27. Grant, C. A., Wallace, L. M., \& Spurgeon, P. C. (2013). An exploration of the psychological factors affecting remote e-worker's job effectiveness, well-being and work-life balance. Employee Relations. https://doi.org/10.1108/ ER-08-2012-0059

28. Ab Hamid, M. R., Sami, W., \& Sidek, M. M. (2017, September). Discriminant validity assessment: Use of Fornell \& Larcker criterion versus HTMT criterion. Journal of Physics: Conference Series, 890(1), 012163). IOP Publishing. Retrieved from https:// iopscience.iop.org/article/10 $.1088 / 1742-6596 / 890 / 1 / 012163 /$ meta
29. Haar, J. M., Russo, M., Suñe, A., \& Ollier-Malaterre, A. (2014). Outcomes of work-life balance on job satisfaction, life satisfaction and mental health: A study across seven cultures. Journal of Vocational Behavior, 85(3), 361-373. https://doi.org/10.1016/j. jvb.2014.08.010

30. Haddon, J. (2018). The impact of employees' wellbeing on performance in the workplace. Strategic HR Review. https://doi. org/10.1108/SHR-01-2018-0009

31. Hair Jr, J. F., Sarstedt, M., Ringle, C. M., \& Gudergan, S. P. (2017). Advanced issues in partial least squares structural equation modeling. SAGE Publications.

32. Hendrie, C. A., \& Pickles, A. R. (2010). Depression as an evolutionary adaptation: anatomical organisation around the third ventricle. Medical Hypotheses, 74(4), 735-740. https://doi.org/10.1016/j. mehy.2009.10.026

33. Hair, J. F., Sarstedt, M., Pieper, T. M., \& Ringle, C. M. (2012). The use of partial least squares structural equation modeling in strategic management research: a review of past practices and recommendations for future applications. Long Range Planning, 45(5-6), 320-340. https://doi. org/10.1016/j.lrp.2012.09.008

34. Hakanen, J. J., Bakker, A. B., \& Schaufeli, W. B. (2006). Burnout and work engagement among teachers. Journal of School Psychology, 43(6), 495-513.https:// doi.org/10.1016/j.jsp.2005.11.001

35. Hartono, J. (2013). Guidance for survey study with questionnaire. BPFE Yogyakarta.

36. Henseler, J., \& Schuberth, F. (2020). Using confirmatory composite analysis to assess emergent variables in business research. Journal of Business Research, 120, 147-156. https://doi. org/10.1016/j.jbusres.2020.07.026

37. Henseler, J., Ringle, C. M., \& Sarstedt, M. (2015). A new criterion for assessing discriminant validity in variancebased structural equation modeling. Journal of the Academy of Marketing Science, 43(1), 115 135. Retrieved from https://link. springer.com/article/10.1007/ s11747-014-0403-8

38. Hobfoll, S. E. (2001). The influence of culture, community, and the nested-self in the stress process: Advancing conservation of resources theory. Applied Psychology, 50(3), 337-421. https:// doi.org/10.1111/1464-0597.00062

39. Hussain, K., Abbas, Z., Gulzar, S., Jibril, A. B., \& Hussain, A. (2020). Examining the impact of abusive supervision on employees' psychological wellbeing and turnover intention: The mediating role of intrinsic motivation. Cogent Business \& Management, 7(1), 1818998. Retrieved from https://doi.org/10.1080/23311975. 2020.1818998

40. Johnson, A., Dey, S., Nguyen, H., Groth, M., Joyce, S., Tan, L., ... \& Harvey, S. B. (2020). A review and agenda for examining how technology-driven changes at work will impact workplace mental health and employee well-being. Australian Journal of Management. https://doi.org /10.1177\%2F0312896220922292

41. Kalliath, T., \& Kalliath, P. (2012). Changing work environments and employee wellbeing: an introduction. International Journal of Manpower. https://doi. org/10.1108/01437721211268285

42. Kaur, K., \& Sandhu, H. S. (2010). Career stage effect on organizational commitment: Empirical evidence from Indian banking industry. International Journal of Business and Management, 5(12), 141. Retrieved from https://www.researchgate. net/publication/49586564_Career_Stage_Effect_on_Organizational_Commitment_Empirical_Evidence_from_Indian_Banking_Industry

43. Khilji, S. E., \& Wang, X. (2006). Intended and implemented HRM: The missing linchpin in strategic human resource management research. The International Journal of Human Resource Management, 17(7), 1171-1189. https://doi. org/10.1080/09585190600756384 
44. Khuwaja, U., Ahmed, D. K., Abid, G., \& Adeel, A. (2020). Leadership and employee attitudes: The mediating role of perception of organizational politics. Cogent Business \& Management. https:// doi.org/10.1080/23311975.2020.1 720066

45. Kossek, E. E., Kalliath, T., \& Kalliath, P. (2012). Achieving employee wellbeing in a changing work environment: An expert commentary on current scholarship. International Journal of Manpower, 33(7), 738-753. https://doi. org/10.1108/01437721211268294

46. Kossek, E. E., Valcour, M., \& Lirio, P. (2014). The sustainable workforce: organizational strategies for promoting worklife balance and wellbeing. In Wellbeing: A complete reference guide (pp. 1-24).

47. Kular, S., Gatenby, M., Rees, C., Soane, E., \& Truss, K. (2008). Employee engagement: A literature review.

48. Kim, M., \& Beehr, T. A. (2018). Challenge and hindrance demands lead to employees' health and behaviours through intrinsic motivation. Stress and Health, 34(3), 367-378. https://doi. org/10.1002/smi.2796

49. Leung, D. Y. P., Lam, T. H., \& Chan, S. S. (2010). Three versions of perceived stress scale: validation in a sample of Chinese cardiac patients who smoke. Public Health. https://doi.org/10.1186/14712458-10-513

50. Lyness, K. S., \& Judiesch, M. K. (2014). Gender egalitarianism and work-life balance for managers: Multisource perspectives in 36 countries. Applied Psychology, 63, 96-129. https://doi.org/10.1111/ apps. 12011

51. McDonald, M. L., \& Westphal, J. D. (2013). Access denied: Low mentoring of women and minority first-time directors and its negative effects on appointments to additional boards. Academy of Management Journal, 56(4), 1169-1198. https:// doi.org/10.5465/amj.2011.0230
52. McGuire, D., \& McLaren, L. (2009). The impact of physical environment on employee commitment in call centres. Team Performance Management: An International Journal. Retrieved from https://www.researchgate. net/publication/200824493_The_ impact_of_physical_environment_on_employee_commitment in_call_centres_The_mediating role_of_employee_well-being

53. Melnyk, B. M., Hrabe, D. P., \& Szalacha, L. A. (2013). Relationships among work stress, job satisfaction, mental healthy lifestyle behaviors in new graduate nurses attending the nurse athlete program: A call to action for nursing leaders. Nursing Administration Quarterly, 37(4), 278-285. https://doi.org/10.1097/ NAQ.0b013e3182a2f963

54. Menguc, B., Auh, S., Yeniaras, V., Katsikeas, C. S. (2017). The role of climate: implications for service employee engagement and customer service performance. Journal of Academic Marketing Science, 45(3), 428-451. Retrieved from https://www.researchgate. net/publication/315437799_The_ role_of_climate_implications_ for_service_employee_engagement_and_customer_service_performance

55. Mills, M. J., Fleck, C. R., \& Kozikowski, A. (2013). Positive psychology at work: A conceptual review, state-of-practice assessment, and a look ahead. The Journal of Positive Psychology, $8(2), 153-164$. Retrieved from https://psycnet.apa.org/record/2013-12469-008

56. Nielsen, K., Abildgaard, J. S., \& Daniels, K. (2014). Putting context into organizational intervention design: Using tailored questionnaires to measure initiatives for worker wellbeing. Human Relations, 67(12), 1537-1560. https://doi. org/10.1177/0018726714525974

57. Nesse, R. M. (2000). Is depression an adaptation? Archives of General Psychiatry, 57(1), 14-20. https:// doi.org/10.1001/archpsyc.57.1.14
58. Nielsen, K., Nielsen, M. B., Ogbonnaya, C., Känsälä, M., Saari, E., \& Isaksson, K. (2017). Workplace resources to improve both employee well-being and performance: A systematic review and meta-analysis. Work \& Stress, 31(2), 101-120. https:// doi.org/10.1080/02678373.2017.1 304463

59. Petrou, P., Demerouti, E., Peeters, M. C., Schaufeli, W. B., \& Hetland, J. (2012). Crafting a job on a daily basis: Contextual correlates and the link to work engagement. Journal of Organizational Behavior, 33(8), 1120-1141. Retrieved from https://www.wilmarschaufeli.nl/ publications/Schaufeli/385.pdf

60. Rahman, A., Björk, P., \& Ravald, A. (2020). Exploring the effects of service provider's organizational support and empowerment on employee engagement and well-being. Cogent Business \& Management, 7(1), 1767329. https://doi.org/10.1080/23311975. 2020.1767329

61. Ross, G. F. (1995). Work stress and personality measures among hospitality industry employees. International Journal of Contemporary Hospitality Management. https://doi. org/10.1108/09596119510095334

62. Stansfeld, B., \& Candy, S. (2006). Psychosocial work environment and mental health - a metaanalytic review. Scandinavian Journal of Work, Environment \& Health, 443-462.

63. Saks, A. M. (2006). Antecedents and consequences of employee engagement. Journal of Managerial Psychology.

64. Saleem, Z., Shenbei, Z., \& Hanif, A. M. (2020). Workplace Violence and Employee Engagement: The Mediating Role of Work Environment and Organizational Culture. SAGE Open, 10(2). https://doi.org/ 10.1177\%2F2158244020935885

65. Schaufeli, W. B. (2013). What is engagement? In Employee engagement in theory and practice (pp. 29-49). Routledge. 
66. Sonnentag, S., \& Frese, M. (2012). Dynamic performance. Oxford library of psychology. The Oxford handbook of organizational psychology, 1, 548-575. Retrieved from http://evidence-based-entrepreneurship.com/content/publications/399.pdf

67. Schaufeli, W. B., Salanova, M., González-Romá, V., \& Bakker, A. B. (2002). The measurement of engagement and burnout: A two sample confirmatory factor analytic approach. Journal of Happiness Studies, 3(1), 71-92. https://doi. org/10.1023/A:1015630930326

68. Siegrist, J., \& Theorell, T. (2006). Socio-economic position and health: the role of work and employment. Social Inequalities in Health: New Evidence and Policy Implications, 73-100. Retrieved fromhttps://oxford. universitypressscholarship. com/view/10.1093/acprof:o so/9780198568162.001.0001/ acprof-9780198568162-chapter-4

69. State Bank of Pakistan (SBP). (2020). Retrieved from http:// www.sbp.org.pk/ (accessed on October 10, 2020).
70. Tan, Z., Roberts, A. C., Lee, E. H., Kwok, K. W., Car, J., Soh, C. K., \& Christopoulos, G. (2020). Transitional areas affect perception of workspaces and employee well-being: A study of underground and aboveground workspaces. Building and Environment, 179(15), 106840. https://doi.org/10.1016/j.buildenv.2020.106840

71. Tasnim, M., Hossain, M. Z., \& Enam, F. (2017). Work-Life Balance: Reality check for the working women of Bangladesh. Journal of Human Resource and Sustainability Studies, 5(1), 75-86. https://doi.org/10.4236/ jhrss.2017.51008

72. Truss, C., Shantz, A., Soane, E., Alfes, K., \& Delbridge, R. (2013). Employee engagement, organisational performance and individual well-being: exploring the evidence, developing the theory.

73. Warr, P. (2003). 20 Well-Being and the Workplace. Wellbeing: Foundations of hedonic psychology, 392. Retrieved from https://books.google.com.pk/
books?hl=en\&lr=\&id=-wIXAw AAQBAJ\&oi=fnd\&pg=PA392\& $\mathrm{dq}=73 . \% 09$ Warr, + P. $+(2003) .+20$ +WellBeing+and+the+Workpla ce.+Wellbeing:+Foundations+of thedonic+psychology, $+392 .+\&$ ots=ZqpZs6keg1\&sig=x6_0pZ4 XKcoRZzk8CzmLU41SpP4\&red ir_esc $=\mathrm{y} \# \mathrm{v}=$ onepage $\& \mathrm{q} \& \mathrm{f}=$ false

74. Worldometer. (2020) Pakistan Population. Retrieved from https:// www.worldometers.info/worldpopulation/pakistan-population/ (accessed on October 10, 2020).

75. Zacher, H., Feldman, D. C., \& Schulz, H. (2014). Age, occupational strain, and wellbeing: A person-environment fit perspective. Research in occupational stress and wellbeing, 12, 83-111. https:// doi.org/10.1108/S1479355520140000012002

76. Zheng, X., Zhu, W., Zhao, H., \& Zhang, C. (2015). Employee Well-being in Organizations: Theoretical model, Scale Development, and Crosscultural Validation. Journal of Organizational Behavior, 36(5). https://doi.org/10.1002/job.1990 